\title{
Running away from Weltschmerz: Global Governance and a Double Challenge for the Future of Multilateralism ${ }^{1}$
}

\section{Rewizorski}

Marek Rewizorski - Dr., Associate Professor in the Institute of Political Science, Faculty of Social Science, University of Gdańsk; 2C/15 ul. Wielkopolska, 78-100 Kolobrzeg, Poland; E-mail: marcuser@ o2.pl

\begin{abstract}
This article addresses challenges facing the designers of global governance, as well as the consequences of the mechanisms that trigger changes to the established international order. The latter, as a social construct and ultimately an ideological projection based on the interests, values and ideas that originated in the West, is challenged by emerging powers seeking to change their status, and by the electorates and antiestablishment movements in western states, who are disillusioned with the asymmetric formula of globalization. The main aim of this article is to analyze the impact of the two aforementioned catalysts of change on the established international order. The analytic approach combines, especially, institutional tools from the field of International Relations (IR), public statements, observations and literature analysis. It deploys content analysis tools, especially metaphors, symbolized by Weltschmerz, a negative scenario of global governance expressed by an inability to act, pessimism regarding the possibility of finding consensus and a belief in the reemergence of the inevitable, almost tectonic divisions between states.
\end{abstract}

Key words: Weltschmerz; international order; global governance; multilateralism; emerging markets; populism

For citation: Rewizorski M. (2019) Running away from Weltschmerz: Global Governance and a Double Challenge for the Future of Multilateralism. International Organisations Research Journal, vol. 14, no 4, pp. 28-47 (in English). DOI: 10.17323/1996-7845-2019-04-02.

\section{Introduction}

Global governance, both in its political and economic dimensions, resembles a normative framework set up by state and non-state actors to "[p]romote cross-border co-ordination and co-operation in the provision or exchange of goods, money, services and technical expertise in defined issue areas of the world economy" [Barnett, Duvall, 2005, pp. 39-75; Moschella, Weaver, 2014, p. 4]. However, this framework is considered highly insufficient and unreliable in the context of the "messy" [Haass, 2010] or "cosmopolitan" [Held, 2003]

${ }^{1}$ The editorial board recieved the article in April 2019.

This article is part of the "Global Economic Governance - Actors, Areas of Influence, Interactions" research project (OPUS, 2016/23/B/HS5/00118) funded by the National Science Centre, Poland. 
multilateralism of the post-crisis era and the related uncertainty as to the direction, speed, intensity and nature of changes, which leave decision-makers helpless.

This article addresses the problem of the challenges facing the designers of global governance, as well as the consequences of the mechanisms that trigger changes to the established international order. The latter, as a social construct and ultimately an ideological projection based on the interests, values and ideas that originated in the West [Luckhurst, 2018; Schirm, 2009], is being questioned from two sides. On the global level, emerging powers and developing states (EMDCs) are increasingly voicing their political aspiration for more influence in world politics, and expressing distinct positions on how to mould international relations [Cooper, Farooq, 2016; Cooper, Thakur, 2018, Kirton, 2013; Mielniczuk, 2013; Stuenkel, 2014; 2015]. On the domestic level, the international order is being questioned by the electorates and anti-establishment movements in western states, who are disillusioned with globalization and its asymmetric formula [Burgoon, 2009; Cox, 2017; Milner, 2018; Rodrik, 2018]. The main aim of this article is to analyze the impact of the two aforementioned catalysts of change on the established international order.

The article is based on an institutional approach to power. It shows how actors are able to steer (or guide) and sometimes constrain "[the] actions and circumstances of others through the rules that exist in structural positional differences in informal and formal institutions" [Barnett, Duvall, 2018, p. 57]. As such, the institutional view departs from two dominant traditions of power analysis in International Relations (IR) which depict power as a resource, or as an actual or potential relationship [Baldwin, 2002]. Apart from institutional tools, the analytic approach combines, especially, public statements, literature analysis, observations and cognitive tools, especially metaphors. The latter bridge our understanding of the social world (ontology), as well as knowledge about the social world (epistemology), as socially constructed and intertwined in a reflexive relationship [Guzzini, 2005]. This article uses the metaphor of Weltschmerz as a negative scenario of global governance expressed by an inability to act, pessimism regarding the possibility of finding consensus and a belief in the re-emergence of the inevitable, almost tectonic divisions between states.

Taking metaphor seriously [See Bousquet, Curtis, 2001; Cienki, Yanow, 2013; Little, 2007] is treated in the first section of the article as a starting point for a discussion about how to look at potential changes to the established international order. The second and third sections are devoted to analysis of the global and local forces posing challenges to the international order. The article concludes with reflections on the implications of the contestation of the international order on both levels of analysis.

\section{Three Scenarios of Global Economic Governance}

In a report published in 2011 entitled Facing the Challenges: Three Scenarios for Global Economic Governance in 2020, a group comprised of 24 researchers from China, the United States and Germany focused on a trend analysis considering the plans of reshaping global political and economic governance [Arnold et al., 2011]. A number of interviews on climate change challenges, nuclear weapons control and the turbulent situation in the global economy were conducted with various decision-makers, intellectuals and practitioners in Washington, Shanghai and Berlin. Regarding the turbulence in the global economy, the researchers focused on discussing the most probable scenarios of global economic govern- 
ance after 2020. They stressed that these scenarios are not prescriptive, and they certainly do not have the character of a complex prognosis. Instead, the researchers considered these scenarios as planning tools allowing for a more proactive (rather than reactive) design of the international economic order, following the rule known since Hippocrates that "an ounce of prevention is better than a pound of cure" [Arnold et al., 2011, p. 2].

The first scenario, which might be seen as idealistic, presumed the existence of an inclusively governed world in which the activities intended to reach the goal of regional economic integration would be increasing, global finance would be subject to much stricter regulations than before the global financial crisis (GFC), and inclusive economic growth on a global scale, guaranteed by the push from emerging markets and relations between China and the United States, would be considerably improved [Arnold et al., 2011, p. 8-11]. The second scenario, decidedly more realistic, was described as "the end of globalization and the beginning of the era of regionalism." It was characterized by the following elements: an increasing significance of stressors, pressures both from the state and substate levels (for instance, from powerful trade associations, the demands of which lead to increasing protectionism and degradation of the global economic environment); economic contraction and anti-market sentiments gaining popularity in western societies; fragmentation and disentanglement of the global economy, and; the emergence of regional trading and financial blocs between western and non-western states, resulting in limited international coordination [Arnold et al., 2011, p. 12-5].

The third, and most dramatic, scenario is described in the report as Weltschmerz. This German term has a long and rich tradition. It originated in the romantic period - the main movement in European culture of the 18th and 19th centuries. The figures that represented it, such as Werther, or the Giaour, experienced a strong "pain of existence," "pain of the world" and melancholy - emotions caused by the constant conflict between the will and an inability to act. This deep sense of sadness, pessimism and wariness, combined with a conviction about the power of evil and the inevitability of suffering became the everyday reality for the late romanticists of the 1830s. Three decades later, the meaning of the term Weltschmerz became altered. The word ceased to describe the mental state of a poet or artist in general, seen as a result of their sensitivity in the face of evil and suffering, and became the key concept shaping the public mentality of the era (1860-1900), in a sense forming its Zeitgeist [Beiser, 2016, p. 1].

The unfolding of mature pessimism in Germany after 1860 is usually analyzed in the context of socio-economic changes in the second half of the 19th century in Europe. One view on the source of Weltschmerz was the disappointment with the fiasco of the Revolutions of 1848 [Beiser, 2016]. A different, more comprehensive attempt to explain the phenomenon of pessimism in the German mentality has focused on the outcomes of the economic crisis of 1873. Representatives of this explanatory current claim that the "great depression" (1874-95), lasting for more than 20 years, caused a sense of cultural despair that spread in Germany [Rosenberg, 1967; Stern, 1961]. Despite its popularity, this explanation is widely criticized. Contemporary commentators of the sociopolitical and cultural changes in 19th century Germany notice that the economic crisis does not as much explain the emergence of the aforementioned phenomenon (which preceded the economic crisis by a decade) as its proliferation as a signum specificum of the spirit of the era [Beiser, 2016, p. 2]. Explanations resorting to the political, social and economic aspects of Weltschmerz often invoke one of 
the most significant social issues of the second half of the 19th century. It considered the aspirations and needs voiced by disenfranchised groups of society - the pauperized working class in the urban centres and rural populations living in disadvantaged conditions, both lacking access to the benefits of the technological advancements of the time. In Germany, the issue of the redistribution of those assets to the poor became the most fundamental problem in the political debate in the 1830s. The lack of effective solutions, despite violent public demonstrations in 1830 and 1848, and the deep political divisions that emerged against this backdrop, are considered to be the fundamental reasons for the wave of pessimism that followed the 1860s. Therefore, it has been argued that this collective depression reflected a deep-seated belief in the impossibility of solving the "great social issue," and led to the conviction that human suffering and evil are inescapable as these are deeply rooted in human nature [Hamerow, 1958, pp. 3-93].

With regard to contemporary times, the aforementioned Weltschmerz expressed in inability to act, pessimism regarding the possibility of finding consensus and a belief in the re-emergence of the inevitable, almost tectonic divisions between states, was employed here as a metaphor allowing for "structuring possibilities for human reasoning and action" [Milliken, 1999, p. 235], central to the way in which we depict and understand (social) reality [Bucher, 2014]. Weltschmerz as the third and negative scenario of global economic governance created by the GG2020 Economic Governance Working Group is characterized by the following elements: the emergence of economic stagnation on global markets which results in the re-emergence of protectionism, exacerbation of competition between China and the United States filled with mutual animosity, accusations and paramilitary rhetoric, and political tensions creating a fertile ground for the informal economy [Arnold et al., 2011, pp. 16-20]. In these circumstances, the experience of Weltschmerz, existential suffering, or anhedonia, becomes a painful experience also in the political and economic sense.

From the current perspective (2019) - eight years after the formulation of the three scenarios of GEG by GG2020 Economic Governance Working Group - the idealistic vision contained in the first scenario certainly did not come true. This can be argued by using the example of the multilateral trading system. Its headquarters, which since the mid-1990s have been located in the World Trade Organization (WTO), resembles a fortress besieged by numerous legions of enemies. Discriminatory trade liberalization, protectionism, and populism have formed a new three-strong alliance which attracts all those disappointed with the effects of trade negotiations while gathering forces under the crumbling foundations of trade multilateralism. The fiascos of the consecutive rounds of trade negotiations have deepened the already-existing divisions between states. Even the most economically developed states, referred to as "the Quad" in 2008 (Japan, Canada, the United States and European Union member states), in 2018 presented radically different outlooks on the role of international trade. States which only recently have been allied now form tactical coalitions directed against each other. A striking example of such a coalition is the European Commission's efforts to establish alternative trade linkages by advancing preferential trade agreements between the EU and Canada, Mexico, Japan, Singapore, Vietnam, Australia, India, New Zealand and Chile all directed against the United States [See IISD, 2018; Johnson, 2019; Tabuchi, Ewing, 2017]. The protectionist decisions of Donald Trump, especially considering the United States' withdrawal from the Trans-Pacific Partnership [Chow et al., 2018], its determination to renegotiate the North American Free Trade Agreement 
(NAFTA), bilateralization of trade relations (for instance, modification to the free trade agreement between the United States and Korea), the "devaluation" of the crown jewel of the multilateral trade system, namely the dispute settlement system, which was the result of the United States blocking the appointment of judges to the WTO appellate body [Petersmann, 2018], increasing tensions regarding trade between neighbouring states (the dispute between the United States and Canada in the aviation, wood and papermaking sectors), or the America-China trade war [Zhang, 2018], are only a small fragment of the overall picture of the turbulence in the West. The WTO ministerial conference in Buenos Aires became the symbol of this lack of unity among members, deep divisions and the limited decision-making potential in the core organization of the international trade regime. The conference in Buenos Aires ended with no consensus on key issues. The negotiations exposed a deep divide between the political establishment and civil society in an unprecedented way, as immediately prior to the ministerial conference, the Argentine host decided to revoke the accreditation of 63 non-governmental organization (NGO) delegates, "frustrating the WTO Secretariat and civil society groups in equal measure" [Hannah, Scott, Wilkinson, 2018].

Events of the eight years which have passed since the formulation of the three scenarios of global economic governance confirm that the second and the third proposed scenarios have partially stood the test of time and are much more accurate in their depiction of an economically discordant multilateralism than the first one. In the "end of globalization" as well as in the Weltschmerz scenario, the researchers enumerated specific catalysts of global changes. The second scenario (the end of globalization and the beginning of the era of regionalism) mentions triggers such as: the bailout of Portugal, Spain and Italy by the EU and the failed austerity program in Greece; subsequent rounds of quantitative easing (QE) that instigate currency wars; the bursting of the property bubble in China; fallout of the Group of 20 (G20) summit in Mexico over currency and trade wars with the Doha round declared dead; and ongoing fragmentation of international finances with the establishment of the Asian Monetary Fund and European Monetary Fund and the nomination of an American managing director to the International Monetary Fund, and also to the European and Asian Monetary Funds [Arnold et al., 2011, p. 6]. In the case of the third scenario, the following mechanisms were considered to be its catalysts: debt crises extending over multiple years in advanced economies; an autarkic turn in U.S. domestic politics; a decrease of economic activity and increase of uncertainty in the global economy; formalization of economic blocs in the East through the issuance of a regional currency, and; increased significance of the informal economy [Ibid., p. 7].

Not all of the aforementioned triggers have taken place; therefore, the predictions made in 2011 differ from the realities of global economic governance as of 2019. The realistic and pessimistic scenarios share a few common points that indicate the appearance of forces shaping global economic governance at the end of the 2010s. These include:

(a) the emergence of an economic order that is an alternative to the western model, centred around China as the new leader, having structural, political and cognitive power at its disposal and criticizing unfair economic and political practices of the West;

(b) deep divisions between states belonging to the West and non-West which may lead to the world economy decelerating; 
(c) increasingly visible anti-market sentiments in western societies that have a potential to generate an autarkic turn in the politics and economies of the leading states of the West, and;

(d) increasing significance of local factors, represented by social groups contesting the establishment and loudly articulating their globalization fatigue, demanding job protection, curbing influxes of migrants and provision of social security by the government.

It can thus be seen that global economic governance as a social construct and an ideological projection based on the interests, values and ideas that originated in the West is challenged from two sides, in both the realistic and pessimistic scenarios. On the global level, emerging powers and developing states are increasingly voicing their political aspiration for more influence in world politics, and expressing distinct positions on how to mould international relations. On the domestic level, the international order is being contested by the electorates and anti-establishment movements in western states, who are disillusioned with globalization and its asymmetric formula.

\section{Emerging Powers and the Contestation of International Order}

International order is being challenged because of the desires of emerging economies (particularly the BRICS grouping of Brazil, Russia, India, China and South Africa) but also some middle powers, such as Turkey, Mexico, Indonesia, Korea and Malaysia, to change their status [cf. Røren, Beaumont, 2019; Stuenkel, 2014]. Emerging powers aim at changing the status quo focusing on the institutionalization of international cooperation which, as the example of China or India shows, takes the form of traditional multilateralism in global forums, bilateralism in the region with selected strategic partners and increasing involvement in clubs such as BRICS [Wulf, Debiel, 2015]. This diverse, three-fold approach is obviously inconsistent but allows for a departure from non-alignment policy and the development of "strategic autonomy" apparent in circumventing the structures constituting the hubs of institutional network associated with the West. This can be exemplified by regional initiatives, such as the Chiang Mai Initiative ${ }^{2}$ or the ASEAN+3 Macroeconomic Research Office (AMRO). ${ }^{32}$ The evolution of BRICS along with BRICS' economic narrative of fastpaced economic growth is also part of this path. Having brought together their heads of state for the first time in 2009, and after admission of South Africa in 2011 [Neethling, 2017] BRICS almost immediately became one of the most important structures in the 21st century [Lukov, 2012; Rewizorski, 2015, p. 58]. Alongside the G20, BRICS has become the most innovative example of non-formalized international cooperation [cf. Larionova, Kirton, 2018]. Having assumed the form of a club of states which is contesting the status quo in international politics, BRICS demonstrates its presence manifesting autonomous positions which are radically different from western thinking patterns, thus criticized. According to Russian deputy foreign minister Sergey Ryabkov "critical remarks themselves are the best sign of the BRICS' importance and the significance of this structure for inter-

${ }^{2}$ An international agreement of 10 members of the Association of Southeast Asian Nations (ASEAN), China, Japan and Korea.

32 Established in Singapore in April 2011 by the states of ASEAN+3 (ASEAN, China, Japan and Korea) to monitor and analyze local economies and support the Chiang Mai Initiative. 
national relations. If this had not been the case, BRICS would have been simply ignored instead of the attempts to talk about its condition in a critical tone" [Russia Beyond, 2016]. Indeed, BRICS members allow themselves to criticize the United States and their allies who are intervening in Libya and Syria [Abdeneur, 2016]; they refrain from criticizing annexation of the Crimea by Russia [Hett, Wien, 2015], reject western sanctions on Iran, express their negative assessment of sluggish western reforms of the voting procedures in the Bretton Woods institutions, and condemn the West for interfering in the internal matters of emerging economies under the guise of ensuring that human rights are protected, and good governance or labour standards observed. This autonomy in expressing views is accompanied by their establishment of competitive institutions which both complement western ones and also force a redistribution of power in favour of emerging powers and developing states, such as the Contingent Reserve Arrangement (CRA) (discussed below) or the New Development Bank (NDB). Consequently, BRICS states try to develop their own narrative, defining problems, suggesting how to solve them and use resources in a way different than the West does. However, the autonomy of each BRICS member to express views and fear of China's political and economic clout may be considered stumbling blocks in developing coalitional behaviour and agreeing on a coherent strategy to harness their relative strengths. According to Zaki Laïdi, BRICS, despite bold political statements, is still "a coalition of sovereign state defenders. While they do not seek to form an anti-western political coalition based on a counter-proposal or radically different vision of the world, they are concerned with maintaining their independence of judgment and national action in a world that is increasingly economically and socially interdependent” [2012, p. 614].

The progressive institutionalization of BRICS, which is particularly observable in the fields of economy and finance, is demonstrated by the agreement reached at the 2013 G20 summit in St. Petersburg to establish a reserve fund of $\$ 100$ billion to ensure the financial liquidity and stability of emerging economies [Larionova, Shelepov, 2015, p. 53; Xing, 2014, p. 13]. This instrument was subsequently confirmed one year later when the agreement to establish a financial reserve for contingencies (such as short-term turbulence in the balance of payments, financial instability, etc.), named the Contingent Reserve Arrangement, was signed at the sixth BRICS summit in Fortaleza. First and foremost, however, the New Development Bank is an institution designed as an alternative to the western system based on the International Monetary Fund (IMF). The NDB was founded by BRICS in 2014 and provided with $\$ 100$ billion of initial capital to finance infrastructural projects in BRICS states, other emerging economies and developing states [BRICS, 2014]. Both institutions the CRA and the NDB - enhance intra-BRICS cooperation on balance of payments pressures and development finances. The former provides public goods for financial stability and the latter contributes to sustainable economic development. Operationalized in 2016, the CRA has capital worth $\$ 100$ billion. Unlike the NDB however, the CRA is funded primarily by China (41\%), followed by India, Russia and Brazil (18\% each), and then South Africa (5\%).

Institutionalization of BRICS is accompanied by pressure on western states to reform the existing global governance structures thereby increasing emerging markets' influence on the Bretton Woods institutions established after World War II, namely the IMF and World Bank. As noted by H.H.S. Viswanathan and S. Soni [2017, p. 16] "The NDB and CRA were established primarily as a result of the inability of the Bretton Woods Institutions, 
i.e., the IMF and the World Bank, to carry out reforms in favour of developing economies. Such has been the influence of developed economies on these institutions that the reform structure of the IMF, which was agreed upon by the G20 group in Seoul, Korea, in 2010, was held hostage by the U.S., as any progress on this front required U.S. Congressional approval." Indeed, the creation of the NDB and CRA may be considered outcomes of the BRICS's intention to reduce reliance on the IMF, the World Bank and the dominance of the U.S. dollar as a reserve currency. In other words, institutionalizing BRICS via the creation of development banks and other financial instruments (such as currency swaps) provides tools "through which these states can make their own decisions around project financing without being held hostage to the codes and voting arrangements of existing development finance institutions (DFIs) over which they have limited influence" [Bertelsmann-Scott et al., 2016, p. 11]. Thus, the new DFIs such as the NDB can be considered as the influencebuilding measures of EMDCs in areas of international development and finance.

Considering the efforts of EMDCs to build institutional capacity and use considerable financial resources to exert influence on the Bretton Woods institutions, there is a question as to whether global economic governance and the established international order may possibly be challenged by emerging powers distancing themselves in the future, acting regionally and selectively by establishing new structures operating independently of the current architecture of global economic governance [cf. Kahler, 2017]. This can be easily envisaged in the area of international trade and finance, where the single currency and the Asian Monetary Fund might bring to life the melancholic image of Weltschmerz. However, it is unlikely that emerging powers will completely contest the established international order and trigger an "empty chair crisis." There is a good deal to indicate that emerging powers, by establishing such institutions as the NDB or CRA which provide an opportunity to circumvent the overburdened global networks of finance and trade, are opting for active participation in a "regime of cooperative decentralization." In the opinion of Eric Helleiner, this "regime" is the outcome of two legacies which emerged in international finance after the global financial crisis, namely centralization and decentralization [2014a; $2014 b ; 2016]$. The first legacy is signalled by strengthened international financial cooperation "including initiatives to create new multilateral institutions such as the G20 Leaders Summit and FSB as well as to bolster existing multilateral features of global financial governance such as the IMF, SDR, and international financial standards" [Helleiner, 2016, p. 1]. The second legacy is discernible in ongoing post-crisis decentralization trends in global financial governance "including support for alternatives to the IMF and the dollar as well as for host country regulation, nationally distinctive rules in sectors such as OTC derivatives, and capital controls" [Ibid., p. 1]. As a post-crisis experience, the coexistence of two legacies in global governance responds not only to the structural realities in financial governance but extends areas of trade or development where western and non-western institutions of global economic governance not only tolerate one another but also closely cooperate. Helleiner's "regime" puts emphasis on the importance of self-determination and autonomy in taking a distinct position and creating institutional structures in order to redistribute power and wealth. Therefore, it can be considered as a mechanism protecting the international political and economic order from complete collapse and actualization of the Weltschmerz scenario. 
Both the centralization and decentralization legacies are a response to the changing conditions of global economic governance and are interwoven in intergovernmental decisions and operations producing something new - cooperative decentralization. The examples of partly successful reforms of the International Monetary Fund alongside the linkages between the CRA, NDB and the institutions of the status quo, namely the IMF and the World Bank, confirm that the states contesting the rules of the game, as well as those defending these rules all pursue moderate cooperation (albeit for different reasons) which is nevertheless conditional, full of mistrust and mutual accusations. In the first case, the IMF's 2010 Quota and Voice Reforms, which were made possible with approval from the U.S. Congress on 18 December 2015, did not undermine the domination of western states in the IMF. As the G7, they account for $43 \%$ of the quota and $41.2 \%$ of votes [Rewizorski, 2017]. Additional financing provided to the IMF by emerging powers has nevertheless resulted in the modest transfer of both the quotas and votes to EMDCs. This mainly concerned China, India, Brazil and Mexico which, having acquired increased decision-making power in the IMF, have been able to maintain the narrative about moderately successful endeavours to democratize global economic governance. In the second instance, the CRA was established as an "alternative circuit" to the IMF which did not, however, result in any steps being taken with a view to leaving the IMF and the World Bank or defying the sense of their continued operation. The newly established institutions were used by emerging states as a tool to exert pressure on the West to change the status quo. New structures emulate western solutions regarding their structures and operating mechanisms.

\section{Populism and the Contestation of International Order}

Contestation of the international order by the electorates from western states and their participation in populist movements appears to be no less dangerous in terms of potential outcomes than the contestation of the status quo by emerging powers. It has already been noted that the challenges to the established international order inherent in the emphasis on the importance of self-determination, autonomy in taking positions and creating institutional structures to redistribute power and affluence, are partially disarmed by a regime of "cooperative decentralization." One can see this phenomenon as a safety valve preventing a complete deconstruction of the international political and economic order, and symbolized by the metaphor of Weltschmerz. This is contrasted with the situation on the domestic (subnational) level where cooperative mechanisms have been undermined by the contestative power of populism. For this reason, domestic contestation of the status quo often takes the form of violent outbursts which have more far-reaching consequences than the questioning of the international order on a global level. By escaping from institutional cooperation and control, the backlash against globalization takes the form of "social security" [cf. Polanyi, 1944] embodied in the destructive activities of populist groups.

Adopting an aggregated definition of populism as "a form of political thinking, or policy which refers to social fears and resentment, and pertains to such social movements whose leaders seek popularity among the public in order to manipulate people and lead them toward nebulous albeit attractively formulated goals" [Marczewska-Rytko, 1995, p. 16; Olszyk 2007, p. 237], it should be noted that populism is widespread in many countries at different levels of social, political and economic development. Populism is char- 
acterized by its criticism of closer international political integration (United Kingdom), opposition to the regulations of the economic and monetary union of the EU (Greece, Spain and Portugal), a programmatic fight against the intellectual elite and a negative attitude toward migrants who are considered a threat to national security (Hungary and Poland), anti-trade nativism (United States), and economic populism (numerous Latin American countries), to name just a few. What diverse populist movements share is their anti-establishment attitude, claiming their right to speak on behalf of "the people" against "elites," their opposition to the liberal market economy and against globalization as a set of institutions and processes that allegedly destroy labour markets, and finally (although not universally) a penchant for authoritarian governance [Cox, 2017; Rodrik, 2018].

Sometimes they are noticed belatedly, as in the case of Brexit or Donald Trump's decisions by which EU leaders have been bewildered [Wilson, 2017]. Domestic contestation of political and economic mechanisms is the foundation of the popularity of populist and anti-establishment parties both on the right side of the political stage (UKIP in the United Kingdom and AFD in Germany) and on the left (the Five Star Movement in Italy, Syriza in Greece and Podemos in Spain). They use their respective electorates' dissatisfaction with the pro-liberalization and pro-globalization elites that divide wealth and influence among themselves in a way that is unfair and socially unacceptable [Frieden, 2018; Rodrik, 2018].

Backlash against "unfair" globalization and the questioning of the established international order by disenfranchised electorates and anti-establishment movements in western states can be exemplified by the interrelations between the outcomes of trade globalization and the frequently dramatic transformations in national labour markets after the global financial crash. A study by M.J. Hicks and S. Devtaj [2017] can serve as the point of departure. The authors estimate that $13 \%$ of jobs in the North American industrial sector were liquidated in 2000-10 due to increased imports. D. Autor, D. Dorn and G.H. Hanson [2016] in turn attributed the $10 \%$ drop in employment in U.S. industrial plants in 19912011 to the "import shock" triggered by excessive competition from imports from China. These researchers estimated that, over the period in question, import shock directly caused the liquidation of 2-2.4 million jobs in U.S. industrial plants. Interestingly, the adverse impact of trade globalization on employment prospects is the leitmotiv of both leftist and right-wing populists who, at the same time, typically do not campaign against technological transformation and workers being replaced by automated manufacturing. Instead, their narrative refers to disregarded needs and neglected demand for benefits that result, for instance, from the global trade system. They strongly resonate with the public when populist leaders give reasons for the lack of economic security, falling income and unemployment, and point to who should be blamed. One of the main "perpetrators" is unfair international trade, confined within a global system shaped by rivalry between the values, ideas and material interests of the electorate on the one hand and the preferences of lobbying groups, who have access to decision-makers with a direct influence on wealth distribution, on the other. Helen Milner [1997] painted a highly intuitive yet accurate picture of this. She noted that "cooperation among nations is affected less by fears of other countries' relative gains or cheating than it is by the domestic distributional consequences of cooperative endeavours. Cooperative agreements create winners and losers domestically; therefore they generate supporters and opponents" [Ibid., p. 9]. 
The opponents of cooperative agreements, who join the ranks of populist movements in great numbers, intuitively point to international trade as a politically sensitive issue. As a result, they choose international trade as the target of their attacks. This is the mechanism of finding a "scapegoat," which is employed with delight by populist leaders who readily blame all economic mishaps on the "foreigners:" Chinese who generate the "import shock," Germans who export unemployment to neighbouring countries where they establish their assembly plants and chain stores, or Mexicans who take jobs away from Americans under the NAFTA agreement. This quite obvious explanation conceals another, much less clear one, which is related to the problem of the redistribution of benefits generated by international trade. The problem here is that sometimes international trade involves forms of competition which are banned at the domestic level (what the U.S. philosopher Michael Walzer termed "blocked exchanges" [1983]), because they violate employment standards (social dumping), environmental protection agreements (use of substances that damage the ozone layer), or the rules of social order. Pursuing projects which are deemed to be prohibited by law or stigmatized in the area of trade emphasizes their political nature, which is associated with the difficult matters of distributive justice that political decision-makers need to resolve. What is meant here in the broad sense is justice, defined as fair and comparable distribution of both economic and non-economic benefits among beneficiaries [Cohen, Greenberg, 1982]. The purpose of economic benefits is to improve the financial well-being of their recipients, while non-economic benefits refer to improved working conditions and access to social benefits [Deutsch, 1985]. For the most part, the allocation of benefits is based on the equality principle [Leung, Bond, 1982; 1984]. Benefits are allocated primarily in relation to results achieved by a group rather than individual achievements [Sampson, $1975]$.

What triggers social dissatisfaction and fuels populism, however, is not inequality as such but unfairness, which is often mistaken for inequality. A survey was published in 2017 in which a group of social psychologists asked respondents why people prefer unequal societies [Starmans, Sheskin, Bloom, 2017], demonstrating that people opt for equality when they are members of small groups. When asked about an ideal model of distributing benefits and resources for large groups (including countries) they preferred inequality. This survey considerably updates our knowledge of preferences concerning the optimal benefit distribution model from the 1970s and 1980s, leading to the conclusion that, while no evidence has been found that inequality at the international level raises protests (pertaining to a multilateral trading system), economic inequalities are erroneously identified with economic (including trading) unfairness. These concerns are deeply rooted in people's experience and result in adopting a certain strategy to prevent opportunistic behaviour (such as operating on the brink of a law which defies moral principles).

\section{Conclusion}

Summing up the above considerations it can be said that the established international order is challenged from two sides. This dual opposition in anchored in the post-war liberal order rooted in the ideas, values, interests and narratives of the West.

On the global level, emerging powers and developing states are increasingly voicing their political aspirations for more influence in world politics, and expressing distinct positions 
on how to mould international relations. Aiming to change the status quo, emerging powers focus on institutionalization of international cooperation in the form of traditional multilateralism in global forums, bilateralism in the region with selected strategic partners and increasing involvement in clubs such as BRICS. Their ambitions may lead to the emergence of an economic order that is an alternative to the western model, centred around China as the new leader, having structural, political and cognitive power at its disposal, and also to the exacerbation of divisions between states belonging to the West and non-West. Their intensity appears to be partially disarmed by a regime of cooperative decentralization. One can see this phenomenon as a safety valve preventing a complete deconstruction of the international political and economic order, and symbolized by the metaphor of Weltschmerz.

This is contrasted with the situation on the domestic (subnational) level where cooperative mechanisms have been undermined by the contestative power of populism. This ideology which presents "the people" as a morally good force and contrasts them against "the elite" gathers the electorates and anti-establishment movements in western states, who are disillusioned with globalization and its asymmetric formula. The contestative power of populism is less notorious than contestation of the status quo at the global level which typically attracts the attention of the public and the media, whereas domestic political changes in individual states frequently go unnoticed. However, increasingly visible anti-market sentiments in western societies have a potential to generate an autarkic turn in the politics and economies of the leading states of the West, and to undermine multilateralism by increasing the significance of local factors represented by social groups loudly articulating their globalization fatigue, demanding job protection, curbing influxes of migrants and provision of social security by governments. The further dismantling of domestic cooperative mechanisms in the West may lead to even more violent outbursts of social dissatisfaction, with more far-reaching consequences than the questioning of the international order on a global level.

Contestation of international order on both levels is characterized by noticeable similarities. One similarity concerns the rejection of the status quo in the international economic and political order, and the demands to ensure a more adequate representation and participation of those disenfranchised in the process of globalization. Another similarity is expressed in the shared belief that more balanced, politically legitimate and coherent cooperation between the contested and the contesting will be feasible only provided that the demands of the latter are taken into consideration. They demand that their material interests, ideas and values, which increase their agency in the mechanisms of global governance, be considered.

Further existence of global governance as a normative framework established in order to address transborder challenges will depend on western political and economic elites becoming more compromise-prone, the redistribution of power, wealth and influence by the beneficiaries of globalization, and the recognition of national autonomy and the right to self-determination of the critics of multilateralism in return for greater efficiency and legitimacy of the global governance in economy and politics. Provided that these conditions are fulfilled, the negative scenarios of the end of globalization and Weltschmerz are unlikely. 


\section{References}

Abdeneur A. (2016) Rising Powers and International Security: The BRICS and the Syrian Conflict. Rising Powers Quarterly, vol. 1, no 1, pp. 109-33. Available at: http://risingpowersproject.com/quarterly/ rising-powers-and-international-security-the-brics-and-the-syrian-conflict/ (accessed 28 April 2019).

Arnold K.M., Breul R., Lou Y., Mylavarapu S., von Roda G.A., Sibal R.D., Xu T., Yang X. (2011) Facing the Challenges. Three Scenarios for Global Economic Governance in 2020. GGF 2020 Working Group on Global Economic Governance, Global Governance 2020. Available at: http://www.ggfutures.net/uploads/attachments/GG2020_2011_econ_facing_the_challenges.pdf (accessed 28 April 2019).

Autor D., Dorn D., Hanson G.H. (2016) The China Shock: Learning From Labor-Market Adjustment to Large Changes in Trade. Annual Review of Economics, vol 8, pp. 205-40. Available at: https://doi. org/10.1146/annurev-economics-080315-015041 (accessed 28 April 2019).

Baldwin D.A. (2002) Power and International Relations. The Handbook of International Relations (W. Carlsnaes, T. Risse, B.A. Simmons (eds)). Thousand Oaks: Sage Press.

Barnett M.N., Duvall R. (2005) Power in International Politics. International Organization, vol. 59, no 1, pp. 39-75. Available at: https://doi.org/10.1017/S0020818305050010 (accessed 28 April 2019).

Barnett M.N., Duvall R. (2018) Organization and the Diffusion of Power. International Organization and Global Governance (2nd Edition) (T.G. Weiss, R. Wilkinson (eds)). New York: Routledge.

Beiser F.C. (2016) Weltschmerz: Pessimism in German Philosophy, 1860-1900. Oxford: Oxford University Press.

Bertelsmann-Scott T., Prinsloo C., Sidiropoulos E., Wentworth L., Wood C. (2016) The New Development Bank: Moving the BRICS From an Acronym to an Institution. SAIIA Occasional Paper No 233, South African Institute of International Affairs. Available at: https://saiia.org.za/research/the-new-development-bank-moving-the-brics-from-an-acronym-to-an-institution/ (accessed 28 April 2019).

Bousquet A., Curtis S. (2011) Beyond Models and Metaphors: Complexity Theory, Systems Thinking and International Relations. Cambridge Review of International Affairs, vol. 24, no 1, pp. 43-62. Available at: https://doi.org/10.1080/09557571.2011.558054.

Bucher B. (2014) Acting Abstractions: Metaphors, Narrative Structures, and the Eclipse of Agency. European Journal of International Relations, vol. 20, no 3, pp. 742-65. Available at: https://doi. org/10.1177\%2F1354066113503481 (accessed 28 April 2019).

Burgoon B. (2009) Globalization and Backlash: Polanyi's Revenge? Review of International Political Economy, vol. 16, no 2, pp. 145-77. Available at: https://doi.org/10.1080/09692290802408832.

BRICS (2014) Agreement on the New Development Bank. Fortaleza, 15 July. Available at: http://www. brics.utoronto.ca/docs/140715-bank.html (accessed 10 October 2018).

Chow D.C.K., Sheldon I., McGuire W. (August 7, 2018) How the United States Withdrawal from the Trans-Pacific Partnership Benefits China. Ohio State Public Law Working Paper No. 451. Available at: https://papers.ssrn.com/sol3/papers.cfm?abstract_id=3228007 (accessed 28 April 2019).

Cienki A., Yanow D. (2013) Why Metaphor and Other Tropes? Linguistic Approaches to Analysing Policies and the Political. Journal of International Relations and Development, vol. 16, no 2, pp. 167-76. Available at: https://doi.org/10.1057/jird.2012.28 (accessed 28 April 2019).

Cohen R.L., Greenberg J. (1982) The Justice Concept in Social Psychology. New York: Academic Press.

Cooper A.F., Farooq A.B. (2016) The Role of China and India in the G20 and BRICS: Commonalities or Competitive Behaviour? Journal of Current Chinese Affairs, vol. 45, no 3, pp. 73-106. Available at https:// journals.sub.uni-hamburg.de/giga/jcca/article/view/997/1004.html (accessed 28 April 2019).

Cooper A.F., Thakur R. (2018) The BRICS in the Evolving Architecture of Global Governance. International Organization and Global Governance (2nd Edition) (T.G. Weiss, R. Wilkinson (eds)). New York: Routledge. 
Cox M. (2017) The Rise of Populism and the Crisis of Globalisation: Brexit, Trump and Beyond. Irish Studies in International Affairs, vol. 28, pp. 9-17. Available at: https://doi.org/10.3318/isia.2017.28.12 (accessed 28 April 2019).

Deutsch M. (1985) Distributive Justice: A Socio-Psychological Perspective. New Haven: Yale University Press.

Frieden J. (2018) The Politics of the Globalization Backlash: Sources and Implications. Paper presented at the Annual Meeting of the American Economics Association, 6 January 2018.

Guzzini S. (2005) A Concept of Power: A Constructivist Analysis. Millennium, vol. 33, no 3, pp. 495-521. Available at: https://doi.org/10.1177\%2F03058298050330031301.

Haass R. (2010) The Case for Messy Multilateralism. Financial Times, 6 January. Available at: https:// www.ft.com/content/18d8f8b6-fa2f-11de-beed-00144feab49a (accessed 28 April 2019).

Hamerow T. (1958) Restoration, Revolution, Reaction: Economics and Politics in Germany, 1815-1871. Princeton: Princeton University Press.

Hannah E., Scott J., Wilkinson R. (2018) The WTO in Buenos Aires: The Outcome and Its Significance for the Future of the Multilateral Trading System. World Economy, vol. 41, no 10, pp. 2578-98. Available at: https://doi.org/10.1111/twec.12657 (accessed 28 April 2019).

Held D. (2003) From Executive to Cosmopolitan Multiculturalism. Taming Globalization: Frontiers of Governance (D. Held, M. Koenig-Archibugi (eds)). Cambridge: Polity Press.

Helleiner E. (2014a) Towards Cooperative Decentralization? The Post-Crisis Governance of Global OTC Derivatives. Transnational Financial Regulation After the Crisis (T. Porter (ed)). Abingdon: Routledge.

Helleiner E. (2014b) The Status Quo Crisis. Oxford: Oxford University Press.

Helleiner E. (2016) Legacies of the 2008 Crisis for Global Financial Governance. Global Summitry, vol. 2, no 1, pp. 1-12. Available at: https://doi.org/10.1093/global/guw006 (accessed 28 April 2019).

Hett F., Wien M. (eds) (2015) Between Principles and Pragmatism Perspectives on the Ukraine Crisis from Brazil, India, China and South Africa. FES Perspective, Friedrich Ebert Stiftung. Available at: http://library.fes.de/pdf-files/id-moe/11354.pdf (accessed 28 April 2019).

Hicks M.J., Devtaj S. (2017) Myth and Reality of Manufacturing in America. Center for Business and Economic Research, Ball State University. Available at: https://conexus.cberdata.org/files/MfgReality. pdf (accessed 28 April 2019).

International Institute for Sustainable Development (IISD) (2018) Update on EU Trade and Investment Negotiations: Japan, Vietnam, Australia, New Zealand, Mexico. IISD Investment Treaty News, 30 July. International Institute for Sustainable Development. Available at: https://www.iisd.org/itn/2018/07/30/ update-on-eu-trade-and-investment-negotiations-japan-vietnam-australia-new-zealand-mexico/ (accessed 28 April 2019).

Johnson K. (2019) While Trump Isolates the U.S., It's 'Let's Make a Deal' for the Rest of the World. Foreign Policy, 3 July. Available at: https://foreignpolicy.com/2019/07/03/while-trump-isolates-u-s-itslets-make-a-deal-for-the-rest-of-the-world-trade-fta-mercosur-eu/ (accessed on 4 July 2019).

Kahler M. (2017) Regional Challenges to Global Governance. Global Policy, vol. 8, no 1, pp. 97. Available at: https://doi.org/10.1111/1758-5899.12392 (accessed 28 April 2019).

Kirton J.J. (2013) G20 Governance for a Globalized World. Farnham: Ashgate.

Laïdi Z. (2012) BRICS: Sovereignty Power and Weakness. International Politics, vol. 49, no 5, pp. 61432. Available at: https://core.ac.uk/download/pdf/35303004.pdf (accessed 28 April 2019).

Larionova M., Kirton J. (eds) (2018) BRICS and Global Governance. New York: Routledge.

Larionova M., Shelepov A. (2015) Is BRICS Institutionalization Enhancing Its Effectiveness? The European Union and The BRICS. Complex Relations in the Era of Global Governance (M. Rewizorski (ed)). Heidelberg, New York: Springer. 
Leung K., Bond M.H. (1982) How Chinese and Americans Reward Task-Related Contributions: A Preliminary Study. Psychologia, vol. 25, no 1, pp. 32-9.

Leung K., Bond M.H. (1984) The Impact of Cultural Collectivism on Reward Allocation. Journal of Personality and Social Psychology, vol. 47, no 4, pp. 793-804. Available at: https://doi.org/10.1037/00223514.47.4.793.

Little R. (2007) The Balance of Power in International Relations: Metaphors, Myths and Models. Cambridge: Cambridge University Press.

Luckhurst J. (2018) The Shifting Global Economic Architecture: Decentralizing Authority in Contemporary Global Governance. Basingstoke: Palgrave Macmillan.

Lukov V. (2012) A Global Forum for the New Generation: The Role of the BRICS and the Prospects for the Future. Available at: http://www.brics.utoronto.ca/analysis/Lukov-Global-Forum.html (accessed 20 October 2018).

Marczewska-Rytko M. (1995) Populizm. Teoria i praktyka polityczna [Populism: Political Theory and Practice]. Lublin: Wydawnictwo UMCS. (in Polish)

Mielniczuk F. (2013) BRICS in the Contemporary World: Changing Identities, Converging Interests. Third World Quarterly, vol. 34, no 6, pp. 1075-90. Available at: https://doi.org/10.1080/01436597.2013.8 02506 (accessed 28 April 2019).

Milliken J (1999) The Study of Discourse in International Relations: A Critique of Research and Methods. European Journal of International Relations, vol. 5, no 2, pp. 225-54. Available at: https://doi.org/1 $0.1177 \% 2$ F1354066199005002003 (accessed 28 April 2019).

Milner H. (1997) Interests, Institutions, and Information. Domestic Politics and International Relations. Princeton: Princeton University Press.

Milner H. (2018) Globalization and Its Political Consequences: The Effects on Party Politics in the West. Paper presented at the Annual APSA Conference, Boston. Available at: https://scholar.princeton.edu/ hvmilner/publications/globalization-and-its-political-consequencesthe-effects-party-politics-west (accessed on 2 July 2019).

Moschella M., Weaver C. (2014) Handbook of Global Economic Governance: Players, Power and Paradigms. London, New York: Routledge.

Neethling T. (2017) South Africa's Foreign Policy and the BRICS Formation: Reflections on the Quest for the 'Right' Economic-Diplomatic Strategy. Insight on Africa, vol. 9, no 1, pp. 39-61. Available at: https://doi.org/10.1177\%2F0975087816674580 (accessed 28 April 2019).

Olszyk S. (2007) "Vox populi vox Dei:" teoria populizmu politycznego ["Vox populi vox Dei:" The Theory of Political Populism]. Annales Universitatis Paedagogicae Cracoviensis: Studia Politologica, vol. 46, no 3, pp. 236-47. Available at: http://bazhum.muzhp.pl/media//files/Annales_Universitatis_Paedagogicae_ Cracoviensis_Studia_Politologica/Annales_Universitatis_Paedagogicae_Cracoviensis_Studia_Politologica-r2007-t3/Annales_Universitatis_Paedagogicae_Cracoviensis_Studia_Politologica-r2007-t3s236-247/Annales_Universitatis_Paedagogicae_Cracoviensis_Studia_Politologica-r2007-t3-s236-247. pdf. (in Polish)

Petersmann E-U. (2018) How Should the EU and Other WTO Members React to Their WTO Governance and WTO Appellate Body Crises? Research Paper No RSCAS 2018/71, Robert Schuman Centre for Advanced Studies. Available at: https://papers.ssrn.com/sol3/papers.cfm?abstract_id=3300738 (accessed 28 April 2019).

Polanyi K. (1944) The Great Transformation: The Political and Economic Origins of Our Time. New York: Farrar \& Rineheart.

Rewizorski M. (2015) Participation of the European Union and the BRICS in the G-20. The European Union and the BRICS: Complex Relations in the Era of Global Governance (M. Rewizorski (ed)). Heidelberg, New York: Springer.

Rewizorski M. (2017) Dużo hałasu o nic? Uwagi o reformie modelu funkcjonowania Międzynarodowego Funduszu Walutowego [A Lot of Noise About Nothing? Comments on the Reform of 
the International Monetary Fund]. Przeglad Politologiczny, vol. 2, pp. 19-37. Available at: https:// www.academia.edu/37596742/Dużo_hałasu_o_nic_Uwagi_o_reformie_modelu_funkcjonowania_ Międzynarodowego_Funduszu_Walutowego_Przegląd_Politologiczny_2017_nr_2. (in Polish)

Rodrik D. (2018) Populism and the Economics of Globalization. Journal of International Business Policy, vol. 1, no 1-2, pp. 12-33. Available at: https://doi.org/10.1057/s42214-018-0001-4 (accessed 28 April 2019).

Røren P., Beaumont P. (2019) Grading Greatness: Evaluating the Status Performance of the BRICS. Third World Quarterly, vol. 40, no 3, pp. 429-50. Available at: https://doi.org/10.1080/01436597.2018.15 35892 (accessed 28 April 2019).

Rosenberg H. (1967) Große Depression und Bismarckzeit [The Great Depression and Bismarck]. Berlin: de Gruyter. (in German)

Russia Beyond (2016). Criticism of BRICS is Indicator of Its Significance - Ryabkov. 8 February. Available at: https://www.rbth.com/world/2016/02/08/criticism-of-brics-is-indicator-of-its-significanceryabkov_565821 (accessed 28 April 2019).

Sampson E. E. (1975) On Justice as Equality. Journal of Social Issues, vol. 31, no 3, pp. 45-64. Available at: https://doi.org/10.1111/j.1540-4560.1975.tb00996.x (accessed 28 April 2019).

Schirm S.A. (2009) Ideas and Interests in Global Financial Governance: Comparing German and US Preference Formation. Cambridge Review of International Affairs, vol. 22, 3, pp. 501-21. Available at: https://doi.org/10.1080/09557570903103992 (accessed 28 April 2019).

Starmans C., Sheskin M., Bloom P. (2017) Why People Prefer Unequal Societies. Nature: Human Behaviour, vol. 1, no 4, pp. 1-7. Available at: https://doi.org/10.1038/s41562-017-0082 (accessed 28 April 2019).

Stern F. (1961) The Politics of Cultural Despair. Berkeley: University of California Press.

Stuenkel O. (2014) Emerging Powers and Status: The Case of the First BRICs Summit. Asian Perspective, vol. 38, no 1, pp. 89-109. Available at: https://doi.org/10.1353/apr.2014.0003 (accessed 28 April 2019).

Stuenkel O. (2015) The BRICS and the Future of Global Order. Lanham: Lexington.

Tabuchi H., Ewing J. (2017) Europe and Japan Near Trade Deal as U.S. Takes Protectionist Path. New York Times, 23 June. Available at: https://www.nytimes.com/2017/06/23/business/europe-japan-tradedeal.html (accessed 4 July 2019).

Walzer M. (1983) Spheres of Justice: A Defence of Pluralism and Equality. Oxford: Martin Robertson.

Wilson G.K. (2017) Brexit, Trump and the Special Relationship. The British Journal of Politics and International Relations, vol. 19, no 3, pp. 543-57. Available at: https://doi.org/10.1177\%2F1369148117713719 (accessed 28 April 2019).

Wulf H., Debiel T. (2015) India's ‘Strategic Autonomy' and the Club Model of Global Governance: Why the Indian BRICS Engagement Warrants a Less Ambiguous Foreign Policy Doctrine. Strategic Analysis, vol. 39, no 1, pp. 27-43. Available at: https://doi.org/10.1080/09700161.2014.980550 (accessed 28 April 2019).

Viswanathan H.H.S., Soni S. (2017) BRICS Role in Global Governance Processes. A Decade of BRICS: Indian Perspectives for the Future (S. Saran (ed)). New Delhi: Observer Research Foundation.

Xing L. (2014) Introduction: Understanding the Hegemony and the Dialectics of the Emerging World Order. The BRICS and Beyond. The International Political Economy of Emergence of a New World Order (L. Xing (ed)). Farnham: Ashgate.

Zhang Y. (2018) The US-China Trade War: A Political and Economic Analysis. Indian Journal of Asian Affairs, vol. 31, no 1-2, pp. 53-74. Available at: https://www.jstor.org/stable/26608823 (accessed 28 April 2019). 


\section{Как избежать «мировой скорби»: глобальное управление и двойной вызов будущему многосторонности ${ }^{1}$}

\section{М. Ревизорский}

Ревизорский Марек - доктор, доцент Института политологии факультета социологии Гданьского университета; Poland, 78-100 Kolobrzeg, ul. Wielkopolska 2C/15; E-mail: marcuser@o2.pl

В статье рассматриваются проблемы, с которыми сталкиваются субъекты глобального управления, а также последствия функционирования его механизмов для сложившегося международного порядка. Последнему как социальной конструкции и в конечном счете идеологической проекции, основанной на интересах, ценностях и идеях, возникших на Западе, бросают вызов растущие державы, стремящиеся изменить свой статус, а также электорат и движения, направленные против истеблишмента в западных странах, разочарованные асимметричной формулой глобализации. Основная цель данной статьи - проанализировать влияние двух вышеупомянутых катализаторов изменений на сложившийся международный порядок. Аналитический подход объединяет, в частности, институциональные инструменты из области международных отношений, изучение публичных заявлений, наблюдения и анализ литературы. В нем используются инструменты контент-анализа, особенно метафоры, символизируемые в статье термином «мировая скорбь» (Weltschmerz), которая - как негативный сценарий глобального управления - выражается в неспособности действовать, пессимизме в отношении возможности достижения консенсуса и уверенности в неизбежном возрождении практически «тектонических разломов» между государствами.

Ключевые слова: «мировая скорбь»; международный порядок; глобальное управление; многосторонность; страны с формирующимися рынками; популизм

Для цитирования: Ревизорский М. (2019) Как избежать «мировой скорби»: глобальное управление и двойной вызов будущему многосторонности // Вестник международных организаций. Т. 14. № 4. С. $28-47$ (на русском и английском языках). DOI: 10.17323/1996-7845-2019-04-02.

\section{Источники}

БРИКС (2014) Соглашение о Новом банке развития. Режим доступа: https://www.ranepa.ru/ciir/ sfery-issledovanij/briks/dokumenty-briks/briks-brazilskoe-predsedatelstvo-2015-2016 (дата обращения: 10.10.2018).

Abdeneur A. (2016) Rising Powers and International Security: the BRICS and the Syrian Conflict // Rising Powers Quarterly. Vol. 1. No. 1. P. 109-133. Режим доступа: http://risingpowersproject.com/ wp-content/uploads/2016/10/vol1.1.Adriana-Erthal-Abdenur.pdf (дата обращения: 28.04.2019).

Arnold K.M., Breul R., Lou Y., Mylavarapu S., von Roda G.A., Sibal R.D., Xu T., Yang X. (2011) Facing the Challenges. Three Scenarios for Global Economic Governance in 2020. Berlin: GG2020 Economic Governance Working Group.

Autor D., Dorn D., Hanson G. (2016) The China Shock: Learning from Labor Market Adjustment to Large Changes in Trade // Annual Review of Economics. No. 8. P. 205-240.

${ }^{1}$ Статья поступила в редакцию в апреле 2019 г.

Статья подготовлена в рамках проекта «Глобальное экономическое управление - акторы, сферы влияния, взаимодействие» (OPUS, 2016/23/B/HS5/00118), финансируемого Национальным научным центром Польши. 
Baldwin D.A. (2002) Power and International Relations. The Handbook of International Relations / W. Carlsnaes, T. Risse, B.A. Simmons (eds). Thousand Oaks: Sage Press.

Barnett M.N., Duvall R. (2005) Power in International Politics // International Organization. Vol. 59. No. 1. P. 39-75.

Barnett M.N., Duvall R. (2018) Organization and the Diffusion of Power. International Organization and Global Governance / T.G. Weiss, R. Wilkinson (eds). N.Y.: Routledge.

Beiser F.C. (2016) Weltschmerz. Pessimism in German Philosophy, 1860-1900. Oxford: Oxford University Press.

Bertelsmann-Scott T., Prinsloo C., Sidiropoulos E., Wentworth L., Wood Ch. (2016) The New Development Bank: Moving the BRICS from an Acronym to an Institution. SAIIA, South African Institute of International Affairs, Occasional Paper 233.

Bousquet A., Curtis S. (2011) Beyond Models and Metaphors: Complexity Theory, Systems Thinking and International Relations // Cambridge Review of International Affairs. Vol. 24. No. 1. P. 43-62.

Bucher B. (2014) Acting abstractions: Metaphors, Narrative Structures, and the Eclipse of Agency // European Journal of International Relations. Vol. 20. No. 3. P. 742-765.

Burgoon B. (2009) Globalization and Backlash: Polayni's Revenge? // Review of International Political Econom. Vol. 16. No. 2. P. 145-77.

Cienki A., Yanow D. (2013) Why Metaphor and Other Tropes? Linguistic Approaches to Analysing Policies and the Political // Journal of International Relations and Development. Vol. 16. No. 2. P. 167-176.

Cohen R.L., Greenberg J. (1982) The Justice Concept in Social Psychology. N.Y.: Academic Press.

Cooper A.F., Farooq A.B. (2016) The Role of China and India in the G20 and BRICS: Commonalities or Competitive Behaviour? // Journal of Current Chinese Affairs. Vol. 45. No. 3. P. 73-106.

Cooper A.F., Thakur R. (2018) The BRICS in the Evolving Architecture of Global Governance. International Organization and Global Governance / T.G. Weiss, R. Wilkinson (eds). N.Y.: Routledge.

Cox M. (2017) The Rise of Populism and the Crisis of Globalisation: Brexit, Trump and beyond. Irish Studies in International Affairs. Vol. 28. P. 9-17.

Deutsch M. (1985) Distributive Justice: A Socio-Psychological Perspective. New Haven: Yale University Press.

Frieden J. (2017) The Politics of the Globalization Backlash: Sources and Implications. Prepared for Presentation at the Annual Meetings of the American Economics Association, panel on "Making Globalization Inclusive.” January 6.

Guzzini S. (2005) A Concept of Power: A Constructivist Analysis // Millennium. Vol. 33. No. 3. P. 495-521.

Hannah E., Scott J., Wilkinson R. (2018) The WTO in Buenos Aires: The outcome and its significance for the future of the multilateral trading system // World Economy. Vol. 41. No. 10. P. 2578-2598.

Haas R. (2010) The Case for Messy Multilateralism // Financial Times. 6 January.

Held D. (2003) From Executive to Cosmopolitan Multulateralism. Taming Globalization: Frontiers of Governance / D. Held, M. Koenig-Archibugi (eds). Cambidge: Polity Press.

Helleiner E. (2014a) Towards Cooperative Decentralization? The Post-Crisis Governance of Global OTC Derivatives. Transnational Financial Regulation After the Crisis / T. Porter (eds). Abingdon: Routledge.

Helleiner E. (2014b) The Status Quo Crisis. Oxford: Oxford University Press.

Helleiner E. (2016) Legacies of the 2008 Crisis for Global Financial Governance // Global Summitry. Vol. 2. No. 1. P. 1-12.

Hamerow T. (1958) Restoration, Revolution, Reaction: Economics and Politics in Germany, 1815-1871. Princeton: Princeton University Press. 
Hett F., Wien M. (eds) (2015) Between Principles and Pragmatism Perspectives on the Ukraine Crisis from Brazil, India, China and South Africa. Berlin: Perspective, Friedrich-Ebert-Stiftung.

Hicks M.J., Devtaj S. (2017) Myth and Reality of Manufacturing in America. Ball State Center For Business and Economic Research.

IISD (2018) Update on EU Trade and Investment Negotiations: Japan, Vietnam, Australia, New Zealand, Mexico. Investment Treaty News International Insitute for Sustainable Development. July 30. Peжим доступа: https://www.iisd.org/itn/2018/07/30/update-on-eu-trade-and-investment-negotiationsjapan-vietnam-australia-new-zealand-mexico (дата обращения: 28.04.2019).

Johnson K. (2019) While Trump Isolates the U.S., It's 'Let's Make a Deal' for the Rest of the World Globalization is Alive and Well. It's just the United States sitting on the sidelines. 3 July. Режим доступа: https://foreignpolicy.com/2019/07/03/while-trump-isolates-u-s-its-lets-make-a-deal-for-the-rest-ofthe-world-trade-fta-mercosur-eu (дата обращения: 04.07.2019).

Kahler M. (2016) Regional Challenges to Global Governance. The Council on Foreign Relations, Part of Discussion Paper Series on Global and Regional Governance.

Kirton J.J. (2013) G20 Governance for a Globalized World. Farnham: Ashgate.

Larionova M., Kirton J. (eds) (2018) BRICS and Global Governance. N.Y.: Routledge.

Larionova M., Shelepov A. (2015) Is BRICS Institutionalization Enhancing Its Effectiveness? The European Union and The BRICS. Complex Relations in the Era of Global Governance / M. Rewizorski (eds). Heidelberg; N.Y.: Springer.

Laïdi Z. (2012) BRICS: Sovereignty Power and Weakness // International Politics. Vol. 49. No. 5. P. 614-632.

Little R. (2007) The Balance of Power in International Relations: Metaphors, Myths and Models. Cambridge: Cambridge University Press.

Leung K., Bond M.H. (1982) How Chinese and Americans Reward Task-Related Contributions: A Preliminary Study // Psychologia. Vol. 25. No. 1. P. 32-39.

Leung K., Bond M.H. (1984) The Impact of Cultural Collectivism on Reward Allocation // Journal of Personality and Social Psychology. Vol. 47. No. 4. P. 793-804.

Luckhurst J. (2018) The Shifting Global Economic Architecture. Decentralizing Authority in Contemporary Global Governance. Basingstoke: Palgrave Macmillan.

Lukov V. (2012) A Global Forum for the New Generation: The Role of the BRICS and the Prospects for the Future. Режим доступа: http://www.brics.utoronto.ca/analysis/Lukov-Global-Forum.html (дата обращения: 20.10.2018).

Marczewska-Rytko M. (1995) Populizm. Teoria i praktyka polityczna. Lublin: Wydawnictwo UMCS.

Mielniczuk F. (2013) BRICS in the Contemporary World: Changing Identities, Converging Interests // Third World Quarterly. Vol. 34. No. 6. P. 1075-1090.

Milliken J. (1999) The Study of Discourse in International Relations: A Critique of Research and Methods // European Journal of International Relations. Vol. 5. No. 2. P. 225-254.

Milner H. (1997) Interests, Institutions, and Information. Domestic Politics and International Relations. Princeton: Princeton University Press.

Milner H.V. (2018) Globalization and its Political Consequences: The Effects on Party Politics in The West. Paper for the Annual APSA Conference. August. Boston MA. Режим доступа: https://scholar. princeton.edu/sites/default/files/hvmilner/files/milner_globalization_political_consequences.pdf (дата обращения: 02.07.2019).

Moschella M., Weaver C. (2014) Handbook of Global Economic Governance. Players, Power and Paradigms. L.; N.Y.: Routledge.

Neethling T. (2017) South Africa's Foreign Policy and the BRICS Formation: Reflections on the Quest for the 'Right' Economic-diplomatic Strategy // Insight on Africa. Vol. 9. No. 1. P. 39-61. 
Olszyk S. (2007) "Vox populi vox Dei”: teoria populizmu politycznego // Annales Universitatis Paedagogicae Cracoviensis. Studia Politologica. Vol. 46. No. 3. P. 236-247.

Petersmann E.-U. (2018) How should the EU and other WTO Members React to their WTO Governance and WTO Appellate Body Crises? RSCAS 2018/71 Robert Schuman Centre for Advanced Studies Global Governance Programme-331, Florence: EUI.

Polanyi K. (1944) The Great Transformation: the Political and Economic Origins of our Time. N.Y.: Farrar\&Rineheart.

Rewizorski M. (2015) Participation of the European Union and the BRICS in the G-20. The European Union and the BRICS. Complex Relations in the Era of Global Governance / M. Rewizorski (ed.). Heidelberg; N.Y.: Springer.

Rewizorski M. (2017) Dużo hałasu o nic? Uwagi o reformie modelu funkcjonowania Międzynarodowego Funduszu Walutowego // Przegląd Politologiczny. Vol. 2. P. 19-37.

Rodrik D. (2018) Populism and the Economics of Globalization // Journal of International Business Policy. Vol. 1. Режим доступа: https://doi.org/10.1057/s42214-018-0001-4 (дата обращения: 02.07.2019).

Røren P., Beaumont P. (2019) Grading Greatness: Evaluating the Status Performance of the BRICS // Third World Quarterly. Vol. 40. No. 3. P. 429-450.

Rosenberg H. (1967) Große Depression und Bismarckzeit. Berlin: de Gruyter.

Russia Beyond (2016) Criticism of BRICS is Indicator of its Significance - Ryabkov. Режим доступа: https://www.rbth.com/world/2016/02/08/criticism-of-brics-is-indicator-of-its-significance-ryabkov_565821 (дата обращения: 02.07.2019).

Sampson E.E. (1975) On Justice as Equality // Journal of Social Issues. Vol. 31. No. 3.

Schirm S.A. (2009) Ideas and Interests in Global Financial Governance: Comparing German and US preference formation // Cambridge Review of International Affairs. Vol. 22. No. 3. P. 501-521.

Starmans C., Sheskin M., Bloom P. (2017) Why People Prefer Unequal Societies // Nature: Human Behaviour. Vol. 1. No. 4. P. 1-7.

Stern F. (1961) The Politics of Cultural Despair. Berkeley, CA: University of California Press.

Stuenkel O. (2014) Emerging Powers and Status: The Case of the First BRICs Summit // Global Governance. Vol. 38. No. 1. P. 89-109.

Stuenkel O. (2015) The Brics and the Future of Global Order. Lanham, MD: Lexington.

Tabuchi H., Ewing J. (2017) Europe and Japan Near Trade Deal as U.S. Takes Protectionist Path. New York Times. Режим доступа: https://www.nytimes.com/2017/06/23/business/europe-japan-tradedeal.html (дата обращения: 04.07.2019).

Walzer M. (1983) Spheres of Justice: A Defence of Pluralism and Equality. Oxford: Martin Robertson.

Wilson G.K. (2017) Brexit, Trump and the Special Relationship // The British Journal of Politics and International Relations. Vol. 19. No. 3. P. 543-557.

Wulf H., Debiel T. (2015) India's ‘Strategic Autonomy' and the Club Model of Global Governance: Why the Indian BRICS Engagement Warrants a Less Ambiguous Foreign Policy Doctrine // Strategic Analysis. Vol. 39. No. 1. P. 27-43.

Viswanathan H.H.S., Soni S. (2017) BRICS Role in Global Governance Processes. A Decade of BRICS: Indian Perspectives for the Future / S. Saran (ed.). New Delhi: Observer Research Foundation. P. 9-18.

Xing L. (2014) Introduction. Understanding the Hegemony and the Dialectics of the Emerging World Order. The BRICS and Beyond. The International Political Economy of Emergence of a New World Order / L. Xing (ed.). Farnham: Ashgate.

Zhang Y. (2018) The US - China Trade War: A Political and Economic Analysis // Indian Journal of Asian Affairs. Vol. 31. No. 1-2. 